\title{
MEGÚJULÓ ENERGIAFORRÁSOK, KÜLÖNÖS TEKINTETTEL A BIOÜZEMANYAG-GYÁRTÁSRA: NEMZETKÖZI KITEKINTÉS
}

\section{RENEWABLE ENERGY SOURCES WITH PARTICULAR REGARD TO BIOFUEL PRODUCTION: INTERNATIONAL OUTLOOK}

\author{
Popp József', Bai Attila² \\ 'DSc, egyetemi tanár, dékánhelyettes, intézetigazgató, Debreceni Egyetem Gazdaságtudományi Kar \\ popp.jozsef@econ.unideb.hu \\ ${ }^{2}$ PhD, egyetemi tanár, Debreceni Egyetem Gazdaságtudományi Kar \\ bai.attila@econ.unideb.hu
}

\begin{abstract}
ÖSSZEFOGLALÁS
Az EU és a hazai energiapolitika célja az olcsó és környezetbarát módon elöállított energia felhasználása, ugyanakkor a növekvő energiaárak és az energiaimport magas részaránya a bioenergia-termelés további növeléséhez vezethet. Az élelmiszernövényekből előállított bioüzemanyagok a földhasználat alakulását, ezen keresztül az élelmiszerellátást is befolyásolják. Az alternatív hajtóanyagok között meghatározó szerepük van a bioüzemanyagoknak, a megújuló energiaforrások beruházásainak finanszírozásában a nap- és szélenergia vezet, az újabb generációs bioüzemanyag-technológia piaci bevezetése pedig még várat magára. A bioüzemanyagok hazai felhasználása gyakorlatilag a kötelező bekeverésnek köszönhető, ezért célszerű a K+F előmozdítása, a jelenleg hatályos kötelező bekeverés arányának növelése és a biometán felhasználásának ösztönzése.
\end{abstract}

\section{ABSTRACT}

The aim of the energy policy in the EU and in Hungary is to use cheap and environmentally friendly energy, but rising energy prices and the high share of the energy imports can lead to further increase in bioenergy production. Biofuels based on agricultural commodities have an impact on land use and hence global food supply. Biofuels play a major role in the use of alternative motor fuels, however, solar and wind energy are preferred in the competition for financial sources in the renewable energy sector, and the market introduction of next-generation biofuels is still unknown. The use of biofuels in Hungary is due to the mandatory blending so it is proposed to increase the share of mandatory blending, to introduce incentives for the use of biometan and support R+D.

Kulcsszavak: energiaellátás, megújuló energia, bioenergia, bioüzemanyag

Keywords: energy supply, renewable energy, bioenergy, biofuel 


\section{BEVEZETÉS}

A népességnövekedés gyorsulása ráirányítja a figyelmet a fosszilis energiahordozó-kapacitások kimerülésére. A kimerülő erőforrások okozta geopolitikai konfliktusok és a környezeti károk radikális technológiaváltás nélkül globális válságot okozhatnak. Az elmúlt évtizedek óriási gazdasági növekedését egyszerủen annak köszönhetjük, hogy rendkívül olcsón tudtuk a természeti erőforrásokat felhasználni a termeléshez, szállításhoz vagy a kényelmesebb életmódhoz. A Földön a lélekszám emelkedésével közel párhuzamosan nőtt az energiafogyasztás is. A kőolajfüggőség és magas kőolajár, a mezőgazdasági termelés költségeinek és a termékek szállítási költségeinek emelkedése, valamint a környezetvédelmi szempontok az alternatív, megújuló energiaforrások kínálta lehetőségekre irányították a politikai döntéshozók figyelmét. Nagyon kevés régió állít elő fosszilis energiát a világon, ráadásul többségében politikailag megbízhatatlan országokról és régiókról van szó, amelyek gyakran a politikai zsarolás eszközeként, stratégiai fegyverként használják az energiaexportot.

Míg a 19. század elejéig a globális energiafelhasználás közel 100\%-át a biomassza adta, addig a gőzgép térhódításával a 20. század elején az összes energiaigény felét már a szén szolgáltatta. Ugyanakkor a belső égésủ robbanómotor feltalálásával (személygépkocsi, repülőgép) fokozatosan emelkedett a kőolaj iránti kereslet, s ezzel párhuzamosan a földgáz-felhasználás is (1. ábra).

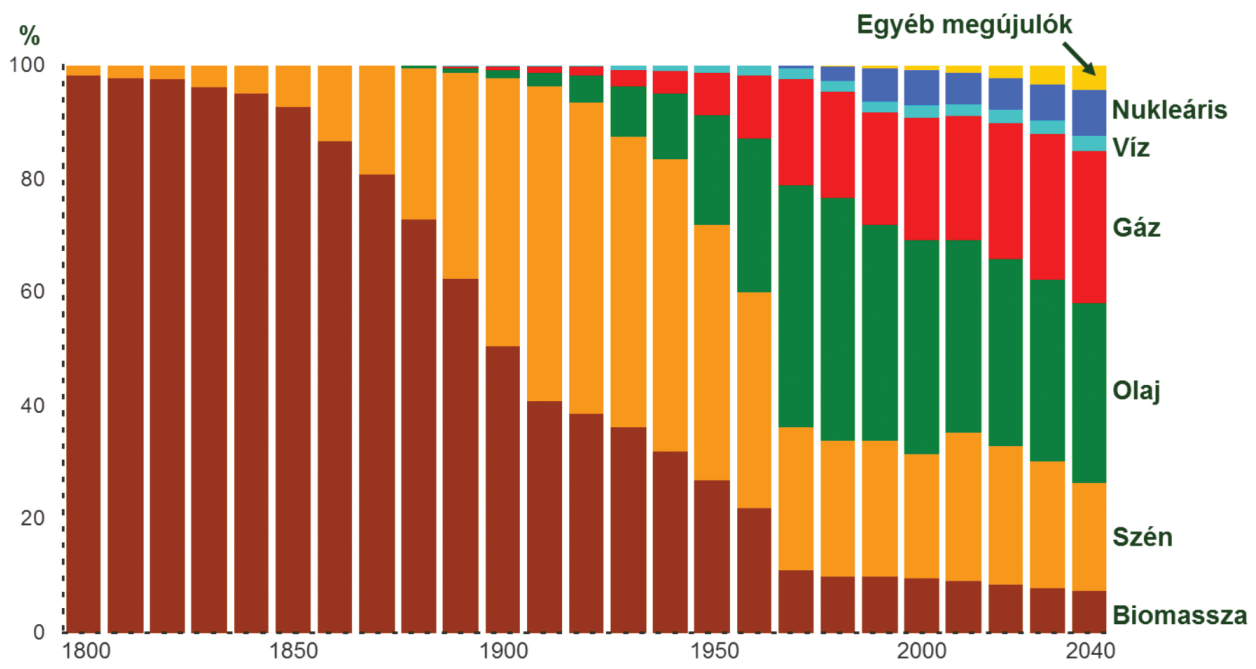

1. ábra. Az energiafelhasználás alakulása a tüzelőanyagok \%-ában

(Smil, 2000 adatai alapján saját szerkesztés) 
A globális népességnövekedés mellett az életmódváltozás miatt (urbanizáció és motorizáció) is emelkedik az emberek átlagos energiafogyasztása. A fejlett országokban az energiahatékonyság javulása mérsékelheti ezt a folyamatot. A növekvő világnépesség tehát hatványozódó (exponenciális) erőforrás-felhasználást eredményez, a fosszilis készletek viszont végesek. Egy növekedésorientált, de fenntarthatatlan világgazdasági rendszerben már az energiatermelés stagnálása is válságot jelent, a csökkenés pedig akár katasztrófát is okozhat. A kőolaj világpiaci árának emelkedése az elmúlt időszakban mindenekelőtt Kína és India ipari termelésének gyors bővülésével magyarázható. A kőolaj kereslete többek között a földgáz és nitrogénmütrágya árának alakulását is befolyásolja. Igaz, hogy a földgáz és a kőolaj piaca közötti kapcsolat manapság lényegesen gyengébb, ami a földgáz keresletének számottevő növekedésével és a földgáz-kereskedelem liberalizációjával magyarázható. A földgáz nehezebben szállítható, ezért kínálata kevésbé rugalmas. Hosszabb távon azonban a földgáz ára igazodik a kőolajéhoz, ugyanis a nagy földgázimportőrök jelentős kapacitásokat építenek ki a cseppfolyósított földgáz (Liquid Natural Gas, LNG) fogadására és tárolására (Popp et al., 2011).

\section{MEGÚJULÓ ENERGIAFORRÁSOK}

A megújuló erőforrások állandóan újratermelődő anyag- és energiaforrások, amelyek hozzájárulnak az energiaellátás biztonságának javításához, a környezetterhelés, különösen a szén-dioxid-kibocsátás csökkentéséhez, a vidékfejlesztéshez és a nemzetközi kereskedelem bővítéséhez. A megújuló energiaforrások növekvő felhasználása mellett az energiahatékonyság és -takarékosság növelése is fontos a fosszilis energia felhasználásának mérsékléséhez, ezzel párhuzamosan az energiaimport-függőségből származó politikai és gazdasági kockázatok csökkentésében. Utóbbiaknak köszönhetően - és az előző évtizedektől eltérően - 2014-ben az energiafogyasztás növekedése $(0,5 \%)$ már alulmúlta a globális GDP növekedését (2,9\%) (Bai, 2016).

Az energiafogyasztás tehát folyamatosan nő, a globális primer energiaellátás - különböző források szerint - 535-576 EJ (exajoule) között alakult 2014-ben (REN21, 2015; IEA, 2015; Enerdata, 2016). A globális végső energiafogyasztásban a fosszilis energia aránya 78\%-ot, a nukleáris energia aránya 3\%-ot, a megújuló energiáé 19\%-ot, ebből 9\%-pontot a bioenergia (biomassza) és 10\%-ot a modern megújuló energia (víz-, szél- és napenergia stb.) tett ki (1. ábra). A megújuló energia termelése 2013-ban már elérte a 76 EJ-t, ami a világ negyedik legnagyobb energiaforrását jelenti a kőolaj, szén és földgáz után. A 76 EJ energiatermelésből a modern megújuló energia (modern fütés, alternatív üzemanyag, villamos energia) 41 EJ volt, a tradicionális biomassza pedig $35 \mathrm{EJ}$. A tradicionális biomassza kétharmadát (tüzifa) még mindig főzésre és fütésre használják fel pazarló módon, elsősorban Afrikában. 
Az elmúlt harmincöt évben a globális energiatermelés megduplázódott, miközben a megújuló energiaforrások hozzájárulása 13\%-ról 19\%-ra nőtt (2. ábra). A felhasznált biomassza a múltban föleg a fára korlátozódott, de ma már egyre inkább hasznosítjuk az energianövényeket, a mezőgazdasági és élelmiszeripari melléktermékeket, az emberi müködés szerves hulladékát és az akvakultúrás biomaszszát is. Összességében a biomassza aránya az elmúlt két évtizedben stabil maradt globális szinten, ugyanakkor a modern megújuló energia felhasználása alacsony szintről indulva gyorsan emelkedett az 1990-es évek második felétől kezdve. Ez azt jelenti, hogy a modern megújuló energia termelése gyorsabb ütemben bővül, mint a biomasszára alapozott bioenergia eloállítása (REN21, 2015; IEA, 2015).

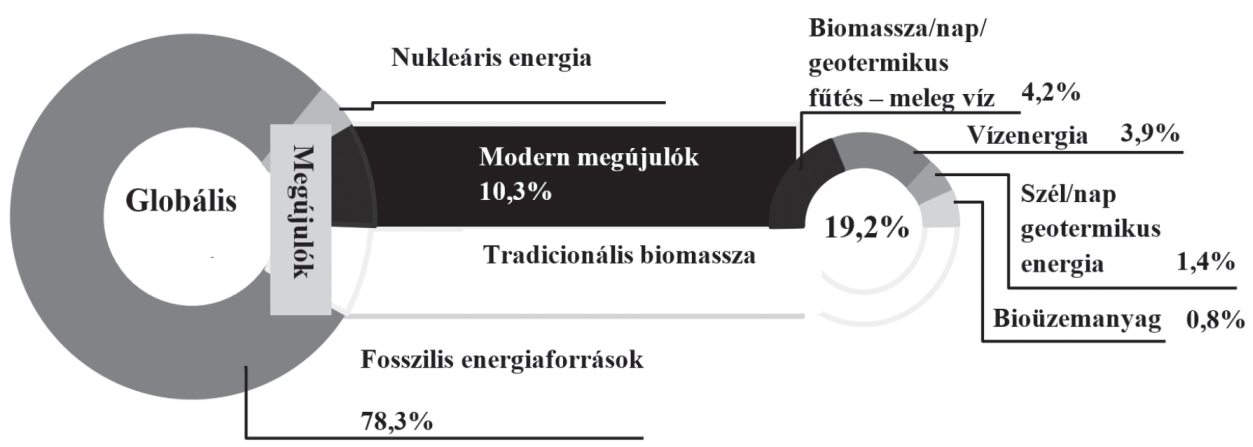

2. ábra. A megújuló energia aránya a globális végső energiafogyasztásban (2014)

(IEA, 2015 adatai alapján saját szerkesztés)

A kőolajkészlet kimerülése nemcsak a közlekedésben okozhat gondot, hanem az ipari termelésben is. Mindezzel csak akkor kell számolnunk, ha belátható időn belül nem következik be technológiai újítás, az energiafelhasználás hatékonyságának javulása, vagy nem állunk át időben és térben megújuló erőforrásokra. A megújulók jelenleg még drágábbak, mint a fosszilis alapú energiatermelés, de a környezetterhelés és a stratégiai kockázatok csökkentése érdekében a kőolajárak alakulásától függetlenül is célszerü lehet váltani megújuló energiaforrásokra.

\section{BIOÜZEMANYAGOK}

A bioüzemanyag ma a globális üzemanyag-fogyasztás 3-4\%-át és a megújulóenergia-előállítás mintegy 5\%-át (3,5 EJ/év) teszi ki (IEA, 2015). A modern bioenergia-termelésben a bioüzemanyag-gyártás azért játszik fontos szerepet, mert a kőolaj több mint 50\%-át a közlekedés használja fel, ahol a kőolajon alapuló 
üzemanyag-felhasználás aránya 96\%. A bioüzemanyag nem tekinthető környezetvédelmi csodaszernek, de a létező technikák körültekintő alkalmazásával elért és elérhető eredményeket nem szabad lebecsülni. A bioüzemanyag-elöállítás szempontjából a biomassza-alapanyagok három generációját különböztetjük meg. A bioetanol elóállításánál az első generációs technológia alapanyaga a nagy keményítő- és cukortartalmú növények (elsősorban kukorica és cukornád), a biodízel-gyártásban pedig az olajnövények (elsősorban repce és szója). A második generációs technológiák magas cellulóztartalmú mezőgazdasági és erdészeti mellékterméket, valamint hulladékokat hasznosítanak. A harmadik generációs technológiák speciális energianövények (lágy és fás szárú energianövények, algák) felhasználásával javítják a bioüzemanyag-ipar versenyképességét és gazdaságosságát (3. ábra).

A világon a ma közlekedő 1,1 milliárd személygépkocsi száma 2040-re várhatóan 2,0 milliárdra emelkedik (Smith, 2016). A közlekedés várható energiaigényének meghatározása igen sok bizonytalansági tényezőt rejt magában, ami befolyásolja a bioüzemanyagok felhasználását is. Ilyen az olajár alakulása, az autógyártási technológiák fejlődése, az energiahatékonyság javulása, illetve az

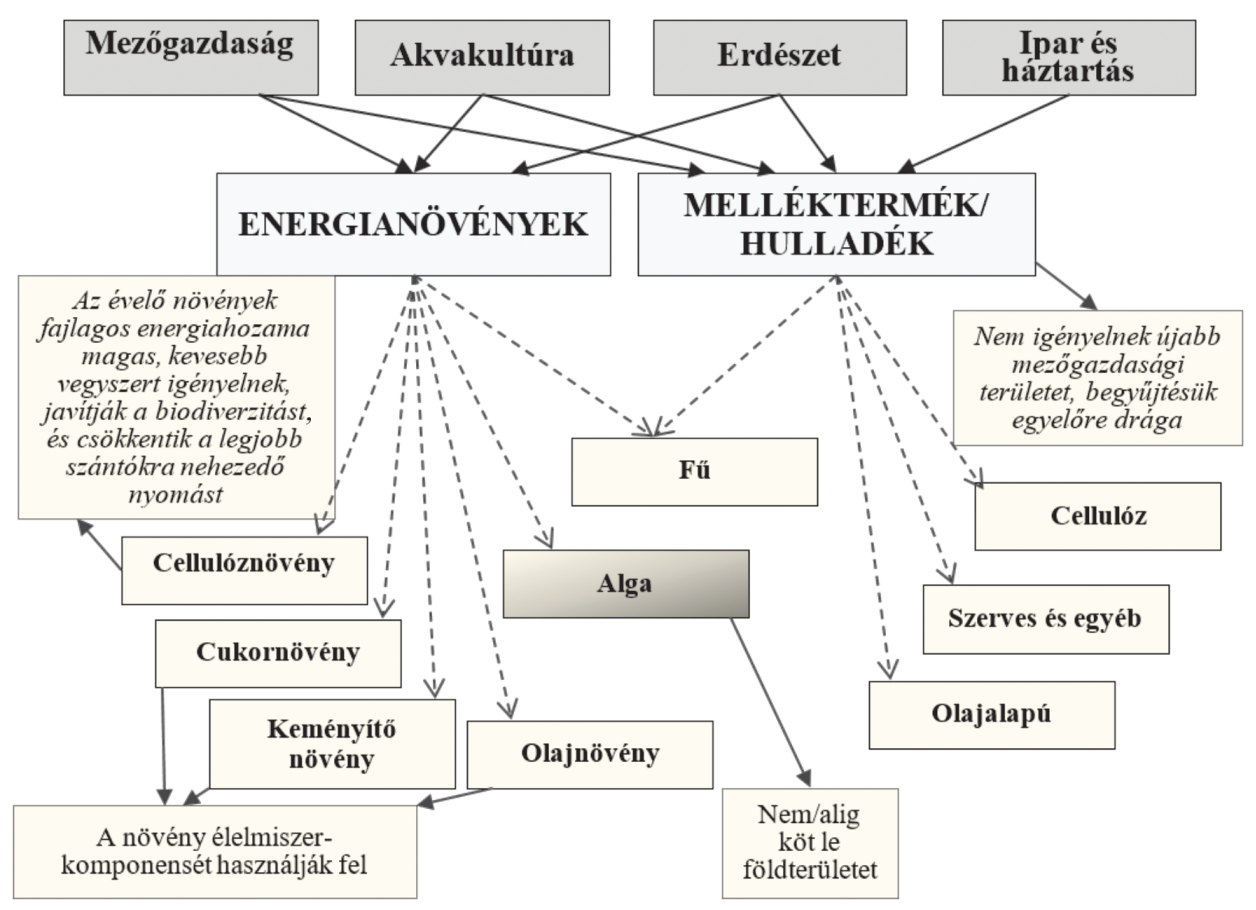

3. ábra. A bioenergia-termelés nyersanyagai

(Saját szerkesztés) 
elöregedett autópark és a közlekedés modernizációja. A bioüzemanyagok használata mellett tehát szükség van az energiahatékonyság javítására is. Nem meglepő, hogy a bioüzemanyag használata, bekeverése a fosszilis üzemanyagba számos országban ajánlott, illetve elöirányzott vagy kötelező.

Ma a folyékony bioüzemanyag $80 \%$-át a bioetanol teszi ki. A 2015-ben elóállított 96 milliárd liter üzemanyagcélú etanol és 31 milliárd liter biodízel a világ üzemanyag-fogyasztásának 3-4\%-át tette ki energia-egyenértékben kifejezve (4. és 5. ábra). Az üzemanyagcélú bioetanol legnagyobb elóállítója az USA, a világpiacot viszont Brazília uralja. Jelentős lemaradással 5,2 milliárd literrel a harmadik legnagyobb termelő az Európai Unió volt. 2025-re az etanol termelése az előrejelzések szerint 128 milliárd literre nő világszerte (OECD/FAO, 2016; RFA, 2016).

2015-ben a globális gabonatermelés mintegy 8-9\%-át használták fel bioüzemanyag-célú etanolgyártásra. A melléktermékek takarmánycélú hasznosítását (DDGS, CGF stb.) is figyelembe véve, az etanolipar nettó gabonafelhasználása a globális termelés csaknem 6\%-ára rúgott. Kukoricából a felhasználás már eléri a világtermelés 15\%-át és az Egyesült Államok termelésének majdnem 40\%-át. Az etanolgyártás másik nyersanyaga, a cukor világpiaca jellemzően keresleti piac, és befolyásolja a brazil etanol nemzetközi kereskedelmét. 2025-ben az etanolgyártás a világ gabonatermelésének 10-11\%-át (nettó 7-8\%-át) fogja igényelni, az USAban a megtermelt kukorica 35\%-a szolgálja majd az etanol-elóállítást. A globális

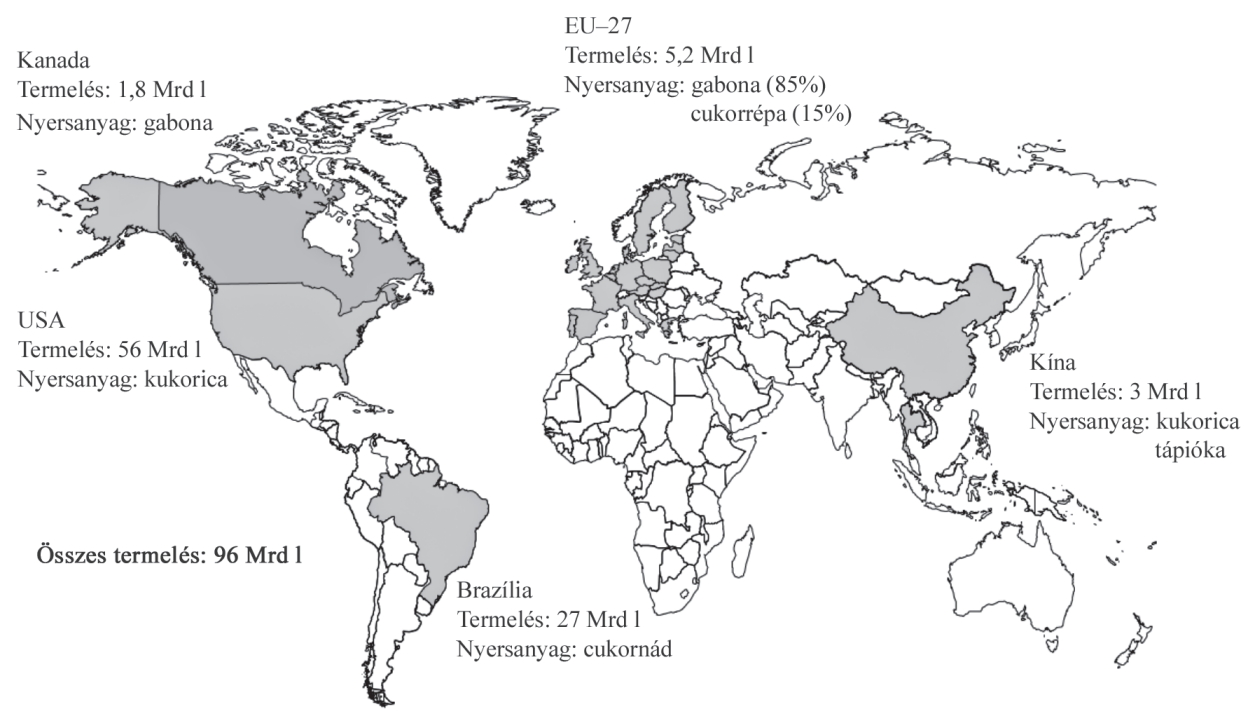

4. ábra. Globális üzemanyagcélú bioetanol-elóállítás (2015)

(OECD/FAO, 2016; RFA, 2016 adatai alapján saját szerkesztés) 


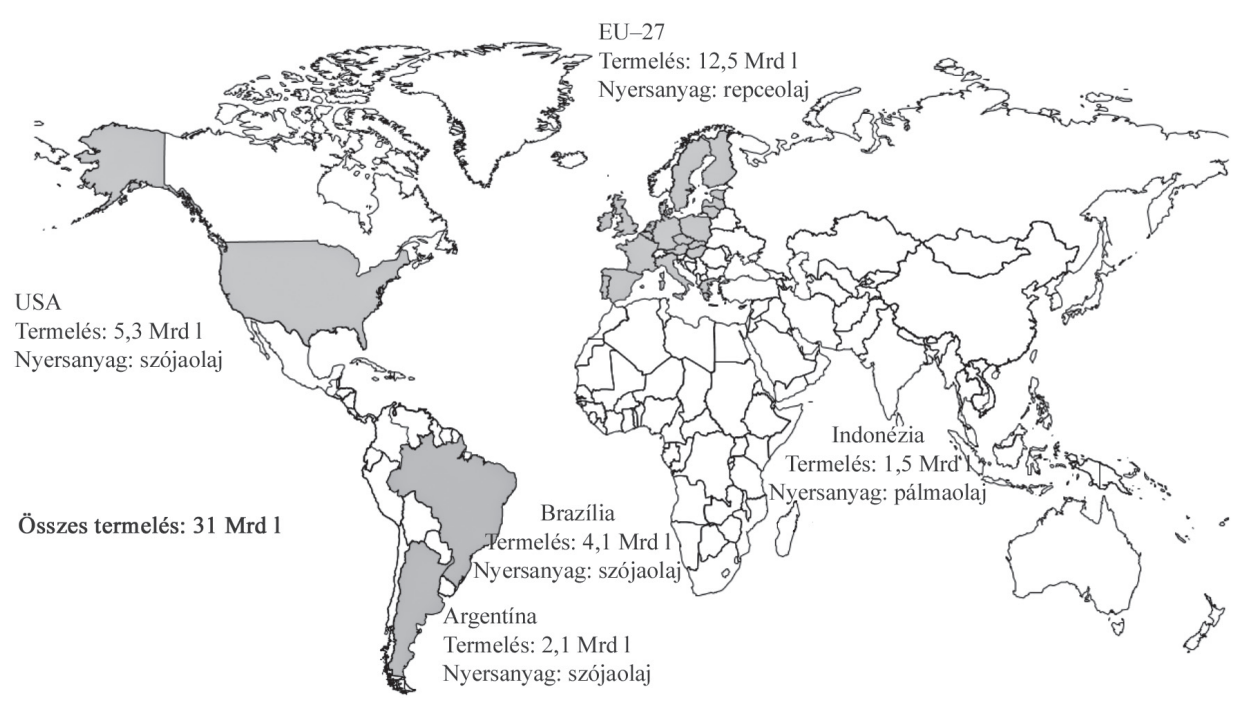

5. ábra. A globális biodízel-termelés alakulása (2015)

(OECD/FAO, 2016; RFA, 2016 adatai alapján saját szerkesztés)

cukornádtermelés etanolcélú felhasználásnak aránya a mai $20 \%$-ról $22 \%$-a nő (OECD/FAO, 2016).

A biodízel-előállítás és -felhasználás ma föleg Európára és kisebb mértékben az USA-ra koncentrálódik, bár az utóbbi években több ország is bekapcsolódott a biodízel-gyártásba. 2015-ben a 31 milliárd liter globális biodízel-termelésből az EU 12,5, az USA 5,3 milliárd litert állított elő (5. ábra). 2025-re a globális biodízelgyártás várhatóan 41 milliárd literre nő (OECD/FAO, 2016; RFA, 2016).

A biodízelgyártás hatása a növényolajok globális piacára már jelentősebb: 2015-ben a globális növényolaj-termelés 11\%-át használták fel e célra, 2025-re ez az arány $12 \%$-ra emelkedik. A legfontosabb nyersanyag a szójaolaj és repceolaj, valamint a pálmaolaj. Az állati zsírokból és a használt sütőolajból is egyre több biodízelt állítanak elő (OECD/FAO, 2016; RFA, 2016).

Az iparág jövője nagymértékben függ a technikai fejlődés sebességétől és a bioüzemanyagok környezeti és társadalmi hatását vizsgáló kutatások eredményétől. Egyes előrejelzések szerint a jövőben a közúti közlekedés energiaigényének jelentôs részét nem az ásványolaj- vagy biomassza-alapú hajtóanyagok fogják kielégíteni, hanem a leginkább környezetbarátnak tekintett hidrogéncellák, illetve elektromos akkumulátorok, amelyek töltéséhez az áramot részben víz-, nap-, szél- és árapály erőmüvekkel állítják elö. E fejlett rendszerek azonban technológiailag még nem kiforrottak, így egyelöre a bioüzemanyagoknak van a gyakorlatban létjogosultságuk. 
Technológiai és jövedelmezőségi problémák miatt az USA kormányzatának a bioüzemanyag-program hosszú távú célértékeit vissza kellett vágnia, ráadásul korlátozza a kukorica felhasználását az etanoltermelésben (legfeljebb 15 milliárd gallon etanol állítható elö, ehhez mintegy 130 millió tonna kukorica szükséges), hogy ne veszélyeztesse az élelmiszer- és takarmányipar nyersanyagellátását (EPA, 2013). Az EU tagállamai vállalták, hogy 2020 -ig uniós szinten 20\%-kal csökkentik az 1990-es szinthez képest az üvegházhatást okozó gázok kibocsátását, továbbá 20\%-ra növelik a megújuló energiaforrások részarányát. Az Európai Bizottság nem változtatta meg a közlekedésben a megújuló forrásból származó üzemanyagok 2020 -ig elérendő (10\%-os) részarányát, a teljesítésben azonban az elsőgenerációs bioüzemanyagok elismerését 7\%-pontban korlátozza. Ennek segítségével tehát az EU-ban is korlátozzák az élelmiszernövényekböl (föleg gabonából, cukorrépából és olajnövényekből) előállított bioüzemanyag mennyiségét. A megújuló forrásból származó energia részaránya az EU teljes energiafelhasználásában 2013-ban 15\% körül alakult, a közlekedésben pedig 5,4\%-ra emelkedett (EEA, 2016). 2020-ra a megújuló energiaforrások arányát 20\%-ra kell növelni, ezen belül a bioüzemanyagok arányát 10\%-ra (energia-egyenértékben kifejezve) tagállami szinten.

Az USA-ban és az EU-ban a jövőben elsősorban a mezőgazdasági melléktermékek - szalma, kukoricaszár, erdészeti, faipari hulladék - felhasználása jöhet szóba a lágy és fás szárú növények mellett. A cellulóztartalmú nyersanyag jelenleg még sokkal olcsóbb, de etanollá történő átalakítása drágább a kukoricánál a cellulóz lebontásához szükséges enzimek magas ára miatt. Továbbá gondot okoz a cellulózalapú nyersanyag betakarítása, tárolása és szállítása, a nagy volumen (2-4-szer nagyobb, mint a gabonafélék és olajnövények szemtermése esetében) és a rövid tárolási lehetőség (kártevők és kórokozók jelenléte) miatt. Ennek költséghatékony logisztikája még hiányzik. Az USA sokkal több pénzt költ a második generációs üzemanyagok kutatására és fejlesztésére, mint az EU. Cellulózalapú folyékony hajtóanyagokból a kísérleti üzemek világszerte elenyésző mennyiséget állítanak elő (Popp et al., 2014), 2016-ban ez mintegy 4 Mrd literre becsülhetö (OECD/FAO, 2016).

A globális szántó- és ültetvényterület mintegy 2\%-át (32 millió hektárt) használja fel a bioüzemanyag-ipar (Langeveld et al., 2014). A felhasznált nyersanyag egy része viszont takarmányként visszakerül az állattenyésztéshez, ezért az energianövények nettó globális földhasználata 1,5\%-ra csökken. Ugyanakkor egyes országok néhány mezőgazdasági ágazatában komoly arányt képvisel a bioüzemanyag-gyártás számára termelt nyersanyag. Brazíliában a cukornádtermelés mintegy 50\%-át használja fel az etanolipar, az USA-ban a kukorica- és szójaterület $20 \%-40 \%$-a szolgálja a bioüzemanyag-gyártást, az EU-ban a repceterület 50-60\%-a biztosít nyersanyagot a biodízeliparnak. A bioüzemanyag-gyártás legfontosabb melléktermékei, a szárított gabonatörköly (DDGS: Distillers Dried Grains with Solubles), a kukorica glutén liszt (CGM: Corn Gluten Meal) és a kukorica glutén takarmány (CGF: Corn Gluten Feed), valamint a szója- és repcedara fontos 
fehérjehordozó takarmányt jelent az állattenyésztés számára. A globális bioüzemanyag-gyártásban az etanolipar évente 45 millió tonna DDG-t, DDGS-t, CGM-t és CGF-t, a biodízelipar pedig a növényolaj felhasználásával közvetve évi 13 millió tonna repcedarát és 28 millió tonna szójadarát állít elő, vagyis szójafehérje-egyenértékben ez megfelel mintegy 65-70 millió tonna szójadarának, azaz az évente világszerte elóállított szójadara 30\%-ának (Popp et al., 2016; Popp et al., 2014).

A jövőben továbbra is éleződő verseny várható a megújuló energiaforrások beruházásainak finanszírozásáért. Az ilyen célú beruházások összege 2004 és 2010 között ötszörösére nőtt, 2010-2016 között évi 234 és 312 milliárd USD között alakult. 2016-ban csökkent a beruházás összege az előző évi 312 milliárd dollárról 242 milliárd dollárra, miközben a megújuló energiaforrások új kapacitásai a 2015. évi 127 GW-ról 2016-ban 138 GW-ra nőttek, föleg a csökkenő fajlagos beruházási költségeknek köszönhetően. A beruházásokban Európa részaránya folyamatosan csökkent, ezzel szemben Kína és az USA részaránya nőtt. A bioüzemanyag-gyártásra beruházott összeg gyorsan nőtt 2004 és 2007 között, de ezután csökkent a beruházás aktivitása az elsőgenerációs bioüzemanyag-előállítás szabályozásának bizonytalansága és a második generációs technológia bevezetésének folyamatos késlekedése miatt. Nem véletlen, hogy 2016-ban a nap- és szélenergia beruházásai a megújuló energiaforrások összes beruházásainak 93\%-át tették ki (Frankfurt School-UNEP Centre/BNEF, 2017).

\section{MAGYARORSZÁG MEGÚJULÓENERGIA-TERMELÉSÉNEK KILÁTÁSAI}

A kormány a 2010-ben elfogadott Nemzeti Megújuló Energia Hasznosítási Cselekvési Tervben vállalta, hogy a megújuló energiaforrások felhasználására vonatkozó 2020-ra érvényes 13\%-os célértéket 14,65\%-ra növeli a teljes energiafelhasználásban a 2010. évi 7,4\%-ról. A kötelezettségvállalás mértékének növelése ellenére Magyarország a tagállamok rangsorában a mezőny alján helyezkedik el.

A megújuló energiaforrások aránya a teljes energiafelhasználásban a Magyar Energetikai és Közmü Hivatal (MEKH) (2017) szerint 9,6\%-ot tett ki 2014-ben, azonban nem hivatalos becslések szerint - figyelembe véve a hivatalos statisztikában nem szereplő, nehezen becsülhető, ám valószínüleg igen jelentős háztartási biomassza-felhasználást - ez elérheti akár a 16\%-ot is. A MEKH hivatalos statisztikája (2017) szerint a megújulók részaránya a fütésben/hütésben 12,3\%-ra, a villamosenergia-elóállításban 7,3\%-ra, a hajtóanyagok tekintetében pedig 6,9\%-ra tehető. A 86 TJ megújuló energia túlnyomó része ( $81 \mathrm{TJ})$ hazai felhasználásra kerül, $5 \mathrm{TJ}$ bioüzemanyagot (az előállított mennyiség 39\%-át) exportálunk. A hazai megújulóenergia-termelés megoszlása a következő értékekkel jellemezhető (MEKH, 2017):

- biomassza: 87\%/75 TJ (ezen belül 68\%/59 TJ szilárd biomassza, 4\%/3 TJ biogáz, 15\%/13 TJ bioüzemanyag); 
- geotermia: 6,3\%/5,4 TJ;

- szél: 2,8\%/2,4 TJ;

- kommunális hulladékok megújuló része: 2,1\%/1,8 TJ;

- víz: $1,3 \% / 1,1 \mathrm{TJ}$;

- nap: 0,5\%/0,5 TJ.

Amennyiben a rejtett biomassza-felhasználást is számításba vesszük, akkor a biomassza részaránya valószínűleg jóval meghaladja a 90\%-ot. Az utóbbi években bekövetkezett növekedés a megújulók részarányában jelentős mértékben az energiatakarékosságnak köszönhető, amelynek eredményeként a hazai energiafogyasztás 2014-re 956 PJ-ra csökkent.

A magyar megújuló energetikai szabályozás az utóbbi években teljesen megváltozott, az új támogatási rendszerben a fö szerepet a biomassza és a geotermikus energia kapja. A vízenergia mennyisége évtizedek óta stagnál, új szélerőmüvek telepítésére nincs kilátás, a napelemek lakossági felhasználása pedig a nemzetközi viszonylatban igen negatívnak értékelhető szabályozás ellenére is nő. A napelemes technológia azonban az utolsó pillanatban is telepíthető, ha ennek segítségével akarunk megfelelni az uniós elvárásoknak.

Magyarországon a biomassza rendelkezik a legnagyobb potenciállal az egyes megújuló energiaforrások között, de az erdészeti biomassza eltüzelése helyett a jövőben az energianövények termesztésére és a mezőgazdasági melléktermékekre lenne indokolt hangsúlyt fektetni. Elöbbiek hatékonyságuknak köszönhetően (egy hektár energetikai faültetvény 10 hektár erdőt mentesít a kivágástól), utóbbiak pedig elsősorban alacsony költségeik, zéró területigényük és helyi felhasználhatóságuk miatt javasolhatók.

A hazai energiapolitikában a rezsicsökkentés gazdaságtalanná teheti a lakossági megújuló energetikai beruházások bővítését, a paksi atomerőmü tervezett kapacitásbővítése pedig a jövőben várhatóan korlátozza a megújuló energia támogatási forrásait. 2015-ben Magyarországon a nukleáris energia a villamosenergia-termelés 53\%-át, a fogyasztás 36\%-át tette ki $(15,8 \mathrm{TWh})$, mely az összes zöld áram 6,5-szerese. Európában ennél magasabb arányt Franciaország (76\%), Ukrajna (62\%), Szlovákia (55\%) és Belgium (54\%) tud felmutatni. Megjegyzendő ugyanakkor, hogy az atomenergia környezetvédelmi szempontból kedvező, és az itt termelt villamos áram akár a hazai közlekedési koncepcióban is szerepet kaphat (elektromos jármüvek). Csökkenti az áramimportot, ám fokozza a technológiát és az alapanyagot beszállító, az ártalmatlanítandó fütőelemeket pedig visszavevő országgal szembeni függésünket. Ugyanakkor ez nemcsak hazai irányvonal. Noha tagállami szinten több ország fogalmazott meg nukleáris energiacsökkentéssel kapcsolatos szándékot, Az európai energiaunió felé címü EU-állásfoglalás (2015/2113 (INI)) egy olyan ,európai energetikai víziót” mutat be, amelyben határozott szándék figyelhető meg az atomenergia irányába. 


\section{IRODALOM}

Az európai energiaunió felé. EU-állásfoglalás (2015/2113 (INI), http://www.europarl.europa.eu/ sides/getDoc.do?pubRef=-//EP//TEXT+REPORT+A8-2015-0341+0+DOC+XML+V0//HU

Bai A. (2016): Visions about a Renewable Future. Trends in Renewable Energy, 2, 2, 51-53.

EEA (2016): Renewable Energy in Europe 2016. European Environment Agency, EEA report No4/2016, Luxembourg 2016, DOI:10.2800/6803, https://www.eea.europa.eu/publications/renewable-energy-in-europe-2016

Enerdata (2016): Global Energy Statistical Yearbook. Paris, https://yearbook.enerdata.net

EPA (2013): Renewable Fuel Standard (RFS), Regulations \& Standards. United States Environmental Protection Agency, https://www.epa.gov/renewable-fuel-standard-program, http:// www.epa.gov/otaq/fuels/renewablefuels/documents/420f13005.pdf

Frankfurt School-UNEP Centre/BNEF (2017): Global Trends in Renewable Energy Investment 2017. Frankfurt am Main, http://fs-unep-centre.org/sites/default/files/publications/globaltrendsinrenewableenergyinvestment2017.pdf

IEA (2015): Renewable Energy. Medium-Term Market Report 2015. Market Analysis and Forecasts to 2020. Paris, France: International Energy Agency, https://www.iea.org/publications/ freepublications/publication/MTRMR2015.pdf

Langeveld, J. W. A. - Dixon, J. - van Keulen, H. - Quist-Wessel, P. M. F. (2014): Analyzing the Effect of Biofuel Expansion on Land Use in Major Producing Countries: Evidence of Increased Multiple Cropping. Biofpr - Biofuels Bioproducts Biorefining. 8, 49-58. DOI: 10.1002/ bbb. 1432

MEKH (2017): Megújuló energiaforrások felhasználásának részaránya 2004-2015. http://www. mekh.hu/eves-adatok

OECD/FAO (2016): OECD-FAO Agricultural Outlook 2016-2025. Paris: OECD Publishing, DOI: 10.1787/agr_outlook-2016-en, https://www.oecd-ilibrary.org/agriculture-and-food/ oecd-fao-agricultural-outlook-2016 agr outlook-2016-en

Popp J. - Harangi-Rákos M. - Gabnai Z. et al. (2016): Biofuels and Their Co-Products as Livestock Feed: Global Economic and Environmental Implications. Molecules, 21, 3, 285 DOI: 10.3390/ molecules21030285, http://www.mdpi.com/1420-3049/21/3/285/htm

Popp J. - Lakner Z. - Harangi-Rakos M. - Fari M. (2014): The Effect of Bioenergy Expansion: Food, Energy, and Environment. Renewable and Sustainable Energy Reviews, 32, 559-578. DOI: 10.1016/j.rser.2014.01.056, https://www.sciencedirect.com/science/article/pii/ S1364032114000677

Popp J. - Potori N. (szerk.) (2011): A biomassza energetikai célú termelése Magyarországon. (Agrárgazdasági Könyvek) Budapest: Agrárgazdasági Kutató Intézet, http://repo.aki.gov.hu/294/

REN21 (2015): Renewables 2015, Global Status Report. Paris, France: Renewable Energy Policy Network for the $21^{\text {st }}$ Century, http://www.ren21.net/wp-content/uploads/2015/07/REN12GSR2015_Onlinebook_low1.pdf

RFA (2016): World Fuel Ethanol Production. Renewable Fuels Association. http://ethanolrfa.org/ resources/industry/statistics/\#1454098996479-8715d404-e546

Smil, V. (2000): Energy Transitions: History, Requirements, Prospects. USA: Praeger, (e-book) www.abc-clio.com

Smith, M. N. (2016): The Number of Cars Worldwide Is Set to Double by 2040. World Economic Forum and Business Insider, 22 April 2016. https://www.weforum.org/agenda/2016/04/thenumber-of-cars-worldwide-is-set-to-double-by-2040 